\title{
The evaluation of the effects of passive smoking on children's health with detection of urine cotinine levels
}

\section{İdrar kotinin düzeylerinin tespiti ile pasif sigara maruziyetinin çocuk sağlığına etkilerinin değerlendirilmesi}

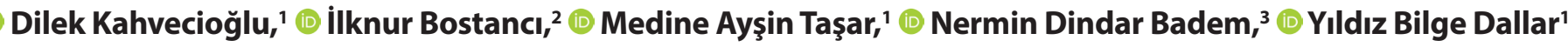 \\ 'Department of Pediatrics, Health Sciences University Ankara Training and Research Hospital, Ankara, Turkey \\ ${ }^{2}$ Department of Pediatric Allergy and Immunology, Health Sciences University Dr Sami Ulus Maternity and Children Training and \\ Research Hospital, Ankara, Turkey \\ ${ }^{3}$ Department of Biochemstry, Kırıkkale University Faculty of Medicine, Ankara, Turkey
}

\begin{abstract}
Introduction: Passive smoking exposure is an important public health problem that causes pneumonia, bronchiolitis, bronchopneumonia, asthma formation and exacerbation, middle ear inflammation, tooth decay, growth retardation and development in children. In this study, it was aimed to evaluate passive smokers objectively by cotinine level in urine.

Methods: Eighty children with at least one active smoker at home and 80 children who were not active smoker at home were admitted to the Ankara Education and Research Hospital . Parents were asked a questionnaire to the sociodemographic characteristics of their children and their families, the habits of smoking and the illnesses they had in a year. To assess passive smoking exposures, the first urine of children was collected and the level of cotinine, the main metabolite of nicotine in the urine, was measured using the solid phase competitive chemiluminescence immunoassay method on the Immulite 2000 Analyzer. A cut-off value of $10 \mathrm{ng} / \mathrm{ml}$ was obtained for diagnosis of passive smoking. Patients with cotinine levels above this value were assessed as "exposed to passive smoking". Results: In passive smoking exposures, the number of illnesses and wheezing has increased in the last year. The preterm birth and wheezing frequency of the smokers were significantly higher in the pregnant women $(p<0.05)$. Median cotinine level was found to be 10 $\mathrm{ng} / \mathrm{ml}$ in the passive smoking group but median cotinine level was found to be $20.8 \mathrm{ng} / \mathrm{ml}$ in the cigarette group $(p<0.01)$. The group with only mother smokers had significantly increased incidence of tooth decay compared with other groups $(p<0.05)$. No relationship was found between birth weigth of infant and smoking behaviour
\end{abstract}

Özet

Amaç: Pasif sigaraya maruz kalma, zatürree, bronşiyolit, bronkopnömoni, astım oluşumu ve alevlenmesi, orta kulak iltihabı, diş çürümesi, büyüme geriliği ve çocuklarda gelişime neden olan önemli bir halk sağlığı sorunudur. Bu çalışmada pasif içicilerin idrarda kotinin düzeyi ile objektif olarak değerlendirilmesi amaçlanmıştır.

Gereç ve Yöntem: Evde en az bir sigara içicisi olan 80 çocuk ve evde sigara içmeyen 80 çocuk Ankara Eğitim ve Araştırma Hastanesi Polikliniğine kabul edildi. Ebeveynlere çocuklarının ve ailelerinin sosyodemografik özelliklerine, sigara içme alışkanlıklarına ve bir yıl içinde sahip oldukları hastalıklara ilişkin bir anket sorulmuştur. Pasif sigara maruziyetlerini değerlendirmek için, çocukların ilk idrarı toplandı ve idrardaki nikotinin ana metaboliti olan kotinin düzeyi, 2000 Analyzer kemilüminesans immünoassay yöntemi kullanılarak ölçüldü. Pasif içiciliğin teşhisi için 10 ng/ml'lik bir kesme değeri elde edildi. Bu değerin üstünde kotinin düzeyine sahip hastalar "pasif sigara içmeye maruz" olarak değerlendirildi.

Bulgular: Pasif sigara içim maruz kalma durumunda, hastalık ve hırıltı sayısı geçen yıl artmıştı. Erken doğum ve hışıltı sıklığı annesi gebeliğinde sigara içenlerde anlamlı derecede yüksekti $(p<0,05)$. Pasif sigara grubunda medyan kotinin seviyesi $10 \mathrm{ng} / \mathrm{ml}$, sigara grubunda medyan kotinin seviyesi 20,8 ng/ml olarak bulundu $(p<0,01)$. Sadece anne sigara içicisi olan grupta, diğer gruplara göre diş çürüğü insidansı fazla idi $(p<0,05)$. Bebeğin doğum ağırlığı ile hamilelikte sigara içme davranışı arasında ilişki bulunmadı $(p=0,53)$, ancak prematürite sıklığı daha yüksek bulundu $(p=0,03)$. Pasif sigara içme grubundaki hastaların \%68,7'sinin ve kontrol

Corresponding (illetişim): İlknur Bostancı, Sağlık Bilimleri Üniversitesi, Dr. Sami Ulus Kadın Doğum, Çocuk Sağlığı ve Hastalıkları Eğitim ve Araştırma Hastanesi, Pediatrik Allerji ve İmmünoloji Kliniği, Ankara, Turkey

E-mail (E-posta): ilknurbbostanci@gmail.com

Received (Geliş Tarihi): 19.03.2019 Accepted (Kabul Tarihi): 26.08.2019 
during pregnancy $(\mathrm{p}=0.53)$, however the frequency of prematurity was found to be higher $(p=0.03)$. The cotinine level of $68.7 \%$ of patients in the passive smoking group and $25 \%$ of the control group was above the threshold value of $10 \mathrm{ng} / \mathrm{ml}$. The most sensitive and specific threshold level of cotinine was found as $14.75 \mathrm{ng} / \mathrm{ml}$.

Discussion and Conclusion: Our study showed that $25 \%$ of children who do not smoke at home are exposed to passive smoking. This finding suggests that families are biased towards reporting smoking cessation alongside their sick children and those children are also exposed to cigarette smoke in out-of-home settings.

Keywords: Child; passive smoking exposure; tobacco products; urine cotinine level. grubunun \%25'inin kotinin seviyesi eşik değerinin $10 \mathrm{ng} / \mathrm{ml}$ 'nin üzerindeydi. En hassas ve spesifik kotinin eşik düzeyi $14,75 \mathrm{ng} / \mathrm{ml}$ olarak bulundu.

Sonuç: Çalışmamız evde sigara içilmediği beyan edilen çocukların \%25'inin pasif sigara içmeye maruz kaldığını göstermiştir. Bu bulgu, ailelerin hasta çocukları ile birlikte sigarayı bırakmalarını bildirme konusunda taraflı olduklarını ve bu çocukların da ev dışı ortamlarda sigara dumanına maruz kaldıklarını göstermektedir.

Anahtar Sözcükler: Çocuk; pasif sigara maruziyeti; tütün ürünleri; idrar kotinin düzeyi.
A ccording to data from the World Health Organisation, approximately half of the world's children are affected by cigarette smoke and the majority of exposure is in the home. ${ }^{[1]}$ The frequency of passive smoking in children in studies conducted in Turkey have been reported at rates ranging from 53\%-81\%. ${ }^{[2,3]}$ In developed countries like USA as maternal level of education increases smoking prevalence nearby children decreases, however studies conducted in Turkey showed that as maternal level of education increases smoking prevalence nearby children increases and prevalance of passive smoking exposure increases too. Studies conducted in Kahramanmaras and Kocaeli pointed out that the frequency of maternal smoking increases as the education level of mother increases. ${ }^{[3-9]}$ Passive cigarette smoke shows its effect mostly on the upper and lower respiratory tract. Passive smoking exposure in both intrauterine and postnatal period increases the frequency of respiratory diseases and causes impairment in lung capacity in children. ${ }^{[6-8]}$

We aimed to assess the passive smoking with the level of cotinine in the urine objectively.

\section{Materials and Method}

\section{Patient characteristics}

A total number of 160 children aged between 2-16 years who admitted Ankara Training and Research Hospital, Children's Outpatient Clinic, were included to study. 80 subjects who are passive smokers (Group I) (at least one active smoker in the house) and 80 subjects (Group II, control) who do not have active smokers at home were enrolled. Parents of children who agreed to participate in the study were applied a questionnaire. The sociodemographic characteristics of children and families, the smoking habit, diseases within the last year were recorded according to the notices of parents. Patients who have had eight or over illness in the last one year were defined as "often sick".[4,5] History of chronic cough (lasting over 6 weeks), wheezing, upper airway infections, pneumonia, asthma and otitis media were recorded. Also tooth decay is recorded.

\section{Data collection and statistical analysis}

First morning urine was collected from all subjects. For the measurement of cotinine levels, at least $5 \mathrm{cc}$ of urine was col- lected in containers that did not contain any preservatives and was taken to $+4^{\circ} \mathrm{C}$ in the refrigerator without delay and no later than one hour were kept frozen at $-20^{\circ} \mathrm{C}$. Cotinine level was measured by the method of solid-phase competitive immunoassay kemoluminesans with Nicotine Metabolite Immulite 2000 Analyzer (PIL2KNM-10) (DPC, USA) device. The "cut-off" value of cotinine was recognized as $10 \mathrm{ng} / \mathrm{ml}$ for the diagnosis of passive smoking. Subjects with cotinine levels above this value were considered as "those who are exposed to passive cigarette smoke".

\section{Exclusion criteria}

Patients with congenital heart disease, immun deficiency and history of atopy in family were excluded.

Data analysis was performed using SPSS for Windows 11.5 package program. Shapiro Wilk test was used to assess the distribution of continuous variables. In determining the cases whether exposed to smoking or not by urinary cotinine measurements was assessed by calculating the area under the ROC curve smoke. If there is an important area under the curve, the best cut-off point for urinary cotinine was determined by using the Youden index. $P$ value $<0.05$ was considered statistically significant .

\section{Results}

A total number of 160 patients aged between 2-15 (7.7 2 3.2) years were enrolled in the study. Children were divided into two groups as 80 patients with passive smoke exposure group and 80 patients in the control group. There was no statistically significant difference in terms of children's age, sex, mother's educational status, father's educational status, income level, and the house type ( $p>0.05$ ). 55\% of cases exposed to cigarette smoke because of parents' behaviour of smoking where the children exist. When two groups were compared (passive smoke exposed and control) according to exposure of indoor smoking, there was a statistically significantly increased incidence of wheezing in the passive smoking exposure group $(p<0.001)$ (Table 1).

Tooth decay incidence was $70.0 \%$ in passive smoking exposure group and $63.7 \%$ in the control group. The group with only mother smokers had significantly increased incidence of 
Table 1. Distribution of diseases and complaints in exposed and non-smokers

\begin{tabular}{|c|c|c|c|}
\hline & $\begin{array}{c}\text { Passive } \\
\text { smoking } \\
(+)(\%)\end{array}$ & $\begin{array}{c}\text { Passive } \\
\text { smoking } \\
(-)(\%)\end{array}$ & $\mathbf{p}$ \\
\hline \multicolumn{4}{|c|}{ Number of diseases } \\
\hline$\leq 8$ & 77.5 & 82.5 & $0.429^{*}$ \\
\hline$<8$ & 22.5 & 17.5 & \\
\hline \multicolumn{4}{|c|}{ Tooth decay } \\
\hline No & 30.0 & 36.3 & $0.401^{*}$ \\
\hline Yes & 70.0 & 63.7 & \\
\hline \multicolumn{4}{|c|}{ Inflammation of the middle ear } \\
\hline No & 67.5 & 76.3 & $0.218^{*}$ \\
\hline Yes & 32.5 & 23.7 & \\
\hline \multicolumn{4}{|l|}{ Cough } \\
\hline No & 10.0 & 21.3 & $0.050^{*}$ \\
\hline Yes & 90.0 & 78.7 & \\
\hline \multicolumn{4}{|c|}{ Wheezing } \\
\hline No & 48.8 & 75.0 & $<0.001^{*}$ \\
\hline Yes & 51.2 & 25.0 & \\
\hline \multicolumn{4}{|c|}{ Upper respiratory disease } \\
\hline No & 3.8 & 1.3 & $0.620^{* *}$ \\
\hline Yes & 96.3 & 98.8 & \\
\hline \multicolumn{4}{|c|}{ Pneumonia } \\
\hline No & 93.8 & 97.5 & $0.443^{* *}$ \\
\hline Yes & 6.2 & 2.5 & \\
\hline \multicolumn{4}{|c|}{ Asthma } \\
\hline No & 95.0 & 92.5 & $0.514^{* *}$ \\
\hline Yes & 5.0 & 7.5 & \\
\hline
\end{tabular}

*Pearson's chi-square test; **Fisher's exact test.

tooth decay compared with other groups ( $p<0.05$ ). $11.2 \%$ of cases'mothers $(n=18)$ were included in the study had smoked during pregnancy. Wheezing was more frequent at the group exposed to tobacco than not -exposed group $(p=0.03)$.

No relationship was found between birth weigth of infant and smoking behaviour during pregnancy $(p=0.53)$, however the frequency of prematurity was found to be higher $(p=0.03)$.

The level of cotinine was over $10 \mathrm{ng} / \mathrm{ml}$ in $68.7 \%$ of the passive smoking exposure group.

The median cotinine level was $10 \mathrm{ng} / \mathrm{ml}(10-169)$ in the the non-exposure group while in passive smoking exposure group was $20.8 \mathrm{ng} / \mathrm{ml}$, respectively ( $\mathrm{p}<0.01$ ).

The level of cotinine in urine was significantly increased according to exposure to tobacco, near-by cigarette smoking, the number of cigarettes smoked, household type and the number of people who smoked at home $(p<0.05)$

The best "cut-off" value of cotinine for distinguishing groups exposed to smoke or not was $14.75 \mathrm{ng} / \mathrm{ml}$. Groups were evaluated in terms of disease within a year, an average number of disease was 5/years in smoke-exposed group and 4/years in non exposed group. This difference was statistically significant $(p<0.001)$.

Data of the patients were examined with multivariate regression analysis. The number of people who smoke in the family had the maximum effect on change in the level of cotinine, than the number of cigarettes and near-by smoking and at least exposure to smoke.

\section{Discussion}

In our study, the educational status of the mothers in the both groups showed that $63 \%$ of mothers had primary-level education status. We could not found a relationship between maternal education and smoking prevalence due to the small number of mothers who graduated from high school or university. Jun et al., ${ }^{[10]}$ reported that low socioeconomic level and being divorced increases maternal cigarette smoking significantly. Whitlock et al. ${ }^{[1]}$ conducted a study with non-smoking 7725 adults reported being in low socio-economic level increases the exposure to passive smoking and exposure of smoking contributes to increase the rate of several diseases and death which have been already seen more frequently in low socio-economic status. ${ }^{[1]}$ In our study $91.3 \%$ of the nonsmoking group and $86.3 \%$ of the smoking group was in low socio-economic status. We believe that families with low socioeconomic level were under more stress than the other families which increases the frequency of cigarette smoking.

Paternal smoking was seen in $81.4 \%$ of the cases and maternal smoking in $26.3 \%$. Bildik et al., ${ }^{[12]}$ reported $24 \%$ maternal, $56.6 \%$ paternal smoking in their study. Karakoç et al., ${ }^{[13]}$ reported $25 \%$ maternal, $42 \%$ paternal smoking in their study. WHO reported the frequency of smoking among females was 20.3\% in Turkey in 2008. ${ }^{[14]}$ The data from our study supports the other studies.

Parents' smoking behaviour was nearby smoking in the 55\% of the cases. Bildik et al., ${ }^{[12]}$ reported the most common smoking places were balcony and kitchen or even in the living room or children's room. Due to preschool children spend a large part of their time at home, therefore indoor smoking negatively influence children's health.

Lux et al., ${ }^{[15]}$ monitored the babies for the first 6 months whose mothers smoked during pregnancy and found that the respiratory function tests were significantly decreased. Gilliland et al. ${ }^{[16]}$ reported that children exposed to smoke during pregnancy, the frequency of wheezing, persistent wheezing, wheezing requiring medication were significantly increased at any time. In our study $11.2 \%$ of the mothers smoked during pregnancy. The frequency of illness in the first year of life in children whose mother smoked during pregnancy was 6 and 4 in the non-smoked group. A statistically significantly increased incidence of wheezing was found in the group whose mother smoked during pregnancy in our study $(p=0.033)$.

In our study, cigarette smoking during pregnancy had no effect on birth weight, whereas there was a significant increase in the risk of prematurity. Ward et al. ${ }^{[17]}$ suggested that to- 
bacco smoke exposure lowered adjusted mean birth weights by $36 \mathrm{~g}$ and caused increases for low birth weight and prematurity in 18297 children (odds ratio: 1.21). Horta et al. ${ }^{[18]}$ conducted a study with 5166 pregnant women and reported that the infants of mothers who smoked during pregnancy weighed an average of $142 \mathrm{~g}$ less at birth than those of nonsmokers. There was no association between preterm delivery and maternal smoking. Maternal smoking during pregnancy causes augmentation in plasental vasculer resistance. Blood flow in uterine artery decreases, oksijen delivery foorm the uterus to the placenta decreases causing chronic hipoxia and increases in hematocrit levels. This changes are among the reasons for intrauterine growth retardation. ${ }^{[19,20]}$ Fenercioğlu et al. ${ }^{[21]}$ compared infants of mothers who were active smoker or non-smoker or pasive smoker for birth weight, height and head circumference. All three parameters were influenced for infants whose mothers were active or passive smoker. Birth weights of infants whose mothers smoked during pregnancy had $246 \mathrm{~g}$ lower than the others and $66 \mathrm{~g}$ lower in infants whose mothers were passive smoker than non-smoking mothers' infants. ${ }^{[21]}$ Keskinoğlu et al. ${ }^{[22]}$ showed the frequency of lower respiratory tract infections (LRTI) increased in the last 2 years in infants with passive smoking. Haberg et al. ${ }^{[23]}$ reported that passive smoking either prenatally, postnatally, or continuously before and after birth increased the risk of experiencing LRTI and wheeze. Prenatal exposure to maternal smoking resulted in higher relative risks than postnatal exposure. The effects of prenatal exposure on the respiratory system had occurred most often around 18 months. Arvas et al. ${ }^{[24]}$ reported that smoking at home especially by the mother increased the frequency of LRTI significantly. Consistent with literature we found a statistically significant difference for the mean number of illness in the last year in the exposure group. Furthermore the frequency of cough and wheezing increased significantly too. Passive cigarette exposure decreases the mucociliary clearance and increases the goblet cell hypertrophy causing chronic cough. ${ }^{[25]}$ Pattenden et al. ${ }^{[26]}$ reported nocturnal cough raised by $12 \%$ for passive smoking exposure. Continuous smoking and exposure to tobacco smoking during the first two years of life were the most important factors increasing the frequency of wheezing. Uyan et al. ${ }^{[27]}$ suggested a raise in the prevelance of recurrent respiratory symptoms in children exposed to smoking. Furthermore they reported breastfeeding protected baby from respiratory illnesses but in babies exposed to smoking this protective effect disappeared.

The incidence of tooth decay was statistically significantly increased in the "only mother smoked group "compared with other groups. Williams et al. ${ }^{[28]}$ reported that only mother smoking increased the prevelance of caries.

Recurent otitis media was seen more frquently in children of mothers who smoke more than 20 cigarettes day but there was no relationship for acute otitis media. ${ }^{[29]}$ Ilıcalı et al. ${ }^{[30]}$ showed increased frequency of both acute and recurrent otitis media in children with passive smoking. We found no relation- ship between exposure to passive smoking and the frequency of acute otitis media in the last year. This may be the results of parents not been questioned about recurrent otitis media, the measurement based on verbal notifications and the ear examination has not been done.

The level of cotinine was over $10 \mathrm{ng} / \mathrm{ml}$ showing tobacco exposure in $68.7 \%$ of the study group and $25 \%$ in the control group. Arvas et al., ${ }^{[24]}$ showed $95.8 \%$ of the study group and $92.7 \%$ of the control group were exposed to smoking acoording to the threshold level of $30 \mathrm{ng} / \mathrm{mg}$ in their study.

$25 \%$ of children who had no cigarette smoker in their home were shown to had been exposed to passive cigarette smoke. This finding suggests that families were biased in reporting smoking frequency and children were exposed to smoking in places outside the home.

The most sensitive and specific threshold level of cotinine was found as $14.75 \mathrm{ng} / \mathrm{ml}$. The median cotinine value was $20 \mathrm{ng} /$ $\mathrm{ml}$ in passive smoking exposure group. Boyacl et al. ${ }^{[3]}$ reported the median level of cotinine as $58 \mathrm{ng} / \mathrm{ml}$ and in Arvas's study as $37.5 \mathrm{ng} / \mathrm{ml}^{[24]}$

The cotinine levels were found to be higher in those who live in slum than those who live in apartment. The concentration of cigarette smoke inside the room changes according to the amount of cigarettes smoked, the volume of room and ventilation of the house. ${ }^{[13]}$ For this reason, those individuals who live in slum houses with small size household and not well-ventilated, was expected to have higher amounts of urine cotinine.

The number of smokers in the house had the greatest impact on the alteration of urinary cotinine levels in our study. Other factors were near-bye smoking and exposure to smoking. Halterman et al. ${ }^{[31]}$ reported that to have an active smoker in the house, to have a primary caregiver who smoked and to have smoking ban in the house were the factors that influenced the cotinine levels. A study from Turkey showed that as the number of persons who smoked in the house and the number of ciagrettes smoked increases, the level of cotinine level increases too. ${ }^{[22]}$

This study examined the effects of passive smoke exposure on children's health and found that urinary cotinine levels were significantly higher in the group with at least one smoker in the house than the control group. In our study, the incidence of wheezing and childhood illness increased in children whose mother smoked during pregnancy. Frequency of caries was found to be increased. As passive smoking exposure begins during pregnancy and is a significant threat for child's health, the community should be educated about the harmful effects of smoking by school-age period and we think that decisive continuation of the legal regulations in the recent period are needed.

Conflict of interest: There are no relevant conflicts of interest to disclose. 


\section{References}

1. Boztaş G, Aslan D, Bilir N. Çevresel Sigara Dumanından Etkilenim ve Çocuklar. Sted 2006;5:75-78.

2. Ersu R, Arman A, Save D. Prevelance of snoring and symptoms of sleep disorded breathing in primary school children in İstanbul . Chest 2004;126:19-24.

3. Boyacı H, Duman C, Başyiğit İ. İlkokul çocuklarında çevresel sigara dumanına maruziyetin idrar kotinin düzeyi ile değerlendirilmesi. Tuberk Toraks 2004;52:231-236.

4. Akşit S. Akut solunum yolu enfeksiyonları. Sted 2002;11:132-135.

5. Ününvar E. Tekrarlayan üst solunum yolu enfeksiyonu olan çocuğun değerlendirilmesi. Journal Of Pediatric İnfection 2007;1: 43-45.

6. Ayata A, Çetin H, Öktem F. Pasif sigara içiminin çocuklarda solunum fonksiyonlarına etkisi. Tıp Araştırmaları Dergisi 2004;2: 1315.

7. Hawamdeh A, Kasasbech F A, Ahmad A M. Effects of passive smoking on children's health. East Meditern Health J 2003; 9: 441-447.

8. Türktaş İ. Çocukluktan Erişkinliğe Akciğer Hastalıkları. Türk Toraks Dergisi 2004; 5: 25-30.

9. Ekerbiçer H C, Çelik M, Güler E. Evaluating envorimental tobacco smoke in a group of Turkish primary school students and developing intervention methods for preventation. BMC Public Health 2007; 7: 1-6.

10. Jun H, Acevedo-Garcia D. The effect of single motherhood on smoking by soscieconomic status and race/ethnicity. Social Science And Medicine 2007; 65: 653-666.

11. Withlock G, Macmahon S, Vander H, Davis P, Jackson R, Norton R. Association of envorimental tobacco smoke exposure with socioeconomic status in a populition of $7725 \mathrm{New}$ Zealanders. Tob. Control 1998; 7: 276-280.

12. Bildik H N, Bilgin E, Demirdöğen E, Yıldız E, Aslan D, Yalçın S. Çocuklar sigara dumanından pasif etkilenim açısından risk altında mı? bir ilköğretim okulu deneyimi. Çocuk Sağlığı ve Hastalıkları Dergisi 2008; 51: 147-152.

13. Karakoç F, Dağlı E, Kut A, Pamukçu A. Çocuklarda pasif sigara maruziyetinin serum kotinin düzeyi ile değerlendirilmesi. Türkiye Klinikleri J Pediatr 1998; 7: 77-82.

14. WHO Report on The Global Tobacco Epidemic, 2008,sayfa 274, http://www.who.int/tobacco/mpower/en/index.html (Son erişim tarihi: 6 Mart 2010).

15. Lux A L, Handerson A J, Pocock S J. Wheeze associated with prenatal tobacco smoke exposure , a prospective longitudinal study, Arch Dis Child 2000; 83: 307-312.

16. Gilliland F D, Li Y F, Peters J M, Effects of maternal smoking during pregnancy and envorimental tobacco smoke on asthma and wheezing in children. Am J Res Critc Care Med 2001;163:429.
17. Ward C, Lewis S, Coleman T. Prevalence of maternal smoking and environmental tobacco smoke exposure during pregnancy and impact on birth weight: retrospective study using millennium cohort. BMC Public Health 2007; 7:81.

18. Horta B L, Victora C G, Menezes A M, Halpern R, Barros F C. Low birthweight, preterm births and intrauterine growth retardation in relation to maternal smoking. Paediatr Perinat Epidemiol. 1997; 11: 140.

19. Difranza J, Aligne A C, Weitzman M. Prenatal and postnatal envorimental tobacco smoke exposure and children's health. Pediatrics 2004; 4: 1007-1015.

20. Bush P G, Mayhew T M, Abramovich D R, Aggett P J, Burke M D, Page K R. Maternal cigarette smoking and oxygen diffusion across the placenta. Placenta 2000; 8: 824-833.

21. Fenercioglu A K, Tamer I , Karatekin G, Nuhoglu A. Impaired postnatal growth of infants prenatally exposed to cigarette smoking. Tohoku J. Exp. Med 2009; 3: 221-228.

22. Keskinoğlu P, Cimrin D, Aksakoğlu G. The impact of passive smoking on the development of lower respiratuar tract infections. Journal Of Tropical Pediatrics 2007; 53: 319 - 324.

23. Haberg E, Stigum H. Effects of pre and postnatal exposure to parental smoking on early childhood respiratuar health. American journal of epidomiology 2007; 166: 679-686.

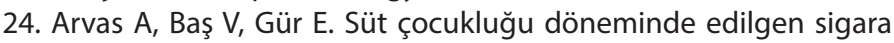
içiminin alt solunum yolu enfeksiyonu gelişimine etkisi. Türk Pediatri Arşivi 2009; 47: 12-17.

25. Cook D, Strachan D. Summary of effects of parental smoking on the respiratory health of children and implications for research. Thorax. 1999; 54: 357-366.

26. Pattenden S, Antova T, Neuberger M, Nikiforov B, De Sario M, Grize $L$ et al. Parental smoking and children's respiratory health: independent effects of prenatal and postnatal exposure. Tob Control. 2006; 15: 294-301.

27. Uyan A P, Baskın E, Özyürek H. Anne sütü alımı ve sigara dumanına maruz kalmanın respiratuvar semptomlara etkisi. Türk Pediatri Arşivi 2002; 37: 29-32

28. Williams S A, Kwan S Y, Parsons S. Parental smoking practices and caries experience in pre-school children. Caries Res.2000; 34:117 $-122$.

29. Ey J L, Holberg C J, Aldous M, Wright A L, Martinez F D, Taussig L M. Passive smoke exposure and otitis media in the first year of life. Pedıatrıcs 1995; 95: 670-677.

30. Ilıcalı Ö C, Keleş N, Değer K. Relationship of passive cigarette smoking to otitis media. Arch Otolaryngolgyhead Neck Surgery 1999; 125: 758-762.

31. Halterman J S, Borrelli B, Tremblay P, Conn K M, Fagnano M, Montes G. Screening for environmental tobacco smoke exposure among Inner city children with asthma. Pediatrics 2008; 122: 1277-1283. 